\title{
Model Pembelajaran Contextual Teaching Learning dalam Pendidikan Agama Kristen untuk Meningkatkan Karakter Siswa Kristiani
}

\author{
Magdalena Elly Kurniawati \\ Fakultas Theologi Universitas Kristen Surakarta, Jawa Tengah, Indonesia \\ magdalena.ely@gmail.com
}

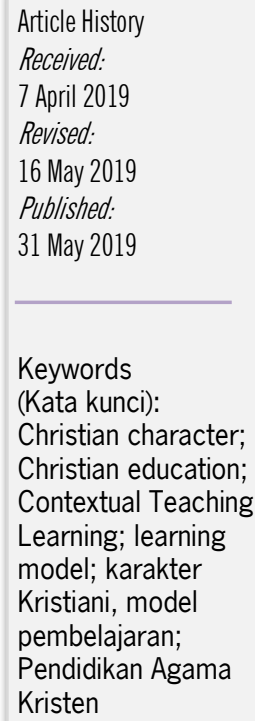

\begin{abstract}
This study aims to examine the effectiveness of the Contextual Teaching Learning (CTL) learning model through Christian Religious Education in improving the Christian character of students in Surakarta 4 Public Middle School. This research was motivated by the fact and condition of Christian students at Surakarta 4th Middle School who experienced a decline due to Christian character. This research applies a participatory research approach with mixed methods research design. Interviews, observations, FGDs and questionnaires were used to collect qualitative and quantitative data. Experiments are used to prove the effectiveness of the model is statistically significant, while field observations and FGDs are used to obtain practical data significant impact of the model. This research is tested as an effective learning model to improve students' character, especially in terms of love, honesty, discipline and responsibility. In qualitative results it can be seen in the attitudes of students who want to carry out tasks without complaining, attend morning services, and are able to understand precisely the essence of Christian character. This research is recommended for curriculum vice principal, teachers, students and future researchers to apply this model. That is because the CTL learning model has proven effective for improving the Christian character of junior high school students.
\end{abstract}

\section{Abstrak}

Penelitian ini bertujuan untuk menguji keefektifan model pembelajaran Contextual Teaching Learning (CTL) melalui Pendidikan Agama Kristen dalam meningkatkan karakter Kristiani siswa di Sekolah Menengah Pertama Negeri 4 Surakarta. Penelitian ini dimotivasi oleh fakta dan kondisi siswa Kristen di SMPN 4 Surakarta yang mengalami kemerosotan berkaitan dengan karakter Kristiani. Penelitian ini menerapkan pendekatan penelitian partisipatif dengan desain penelitian metode campuran. Wawancara, observasi, FGD dan angket digunakan untuk mengumpulkan data kualitatif dan kuantitatif. Eksperimen digunakan untuk membuktikan efektivitas model secara statistikal signifikan, sedangkan observasi lapangan dan FGD digunakan untuk memperoleh data secara praktikal signifikan dampak model. Penelitian ini teruji sebagai model pembelajaran yang efektif untuk meningkatkan karakter siswa, khususnya dalam hal kasih, kejujuran, kedisiplinan dan tanggungjawab. Dalam hasil kualitatif terlihat dalam sikap siswa yang mau melaksanakan tugas tanpa mengeluh, mengikuti ibadah pagi, dan mampu untuk memahami dengan tepat esensi dari karakter Kristiani. Penelitian ini direkomendasikan bagi wakasek kurikulum, guru, siswa dan peneliti selanjutnya untuk menerapkan model ini.Hal itu karena model pembelajaran CTL telah terbukti efektif untuk meningkatkan karakter Kristiani siswa SMP. 


\section{Pendahuluan}

Pendidikan Kristen (PAK) adalah suatu proses pendidikan dan pengajaran yang diberikan di sekolah-sekolah Kristen maupun dalam suasana Kristen. PAK memiliki arti suatu pendidikan yang berfungsi sebagai penyampaian kebenaran yang dinyatakan Tuhan dalam Alkitab. ${ }^{1}$ Pendidikan Agama Kristen merupakan pendidikan yang berpangkal kepada persekutuan umat Tuhan yang bersumber pada Allah sendiri, karena Allah yang menjadi Pendidik Agung bagi umatNya. Pada jaman Perjanjian Lama, pendidikan dimulai dari rumah tangga (keluarga), dan diteruskan dalam kebaktiankebaktian umum serta di dalam pengajaran tentang Taurat Tuhan. Demikian juga di dalam Perjanjian Baru, Tuhan Yesus telah memberikan teladan bagaimana mengajarkan dan menyampaikan pendidikan dengan baik. Itu sebabnya Ia disebut juga sebagai guru Agung.

Dalam menyampaikan pendidikan dibutuhkan suatu acuan dan pedoman yaitu kurikulum agar tujuan dari pendidikan dapat tercapai. Pengembangan kurikulum membutuhkan landasan-landasan agama, filsafat, psikologi, sosial budaya dan ilmu serta teknologi. Agama memberikan landasan tentang nilai, filsafat tentang pendidik, peserta didik dan perbuatan mendidik, psikologi tentang perkembangan dan pembelajaran, sosial budaya tentang isi dan lingkungan pendidikan, sedangkan ilmu dan teknologi tentang isi akan ilmu pendidikan dan media pendidikan. Beberapa fenomena menunjukkan bahwa Pendidikan Agama Kristen masih terus berupaya secara maksimal membentuk karakter siswa. ${ }^{2}$ Siswa diajarkan untuk dapat mengintegrasikan nilai-nilai yang diajarkan dalam kehidupan mereka.

Secara psikologi anak pada usia Sekolah Menengah Pertama (SMP) merupakan masa yang penuh gejolak dan peralihan. Siswa sudah mulai marak menampilkan sikap dengan karakter yang kurang baik, seperti terlibat dalam tawuran, pornografi, penggunaan alkohol, bahkan hingga pembunuhan. Kurikulum harus dapat memunculkan model pembelajaran yang tepat dalam menyampaikan suatu materi yang terkandung dalam PAK untuk anak SMP agar mereka memiliki karakter yang kuat, dan kokoh dalam menyikapi persoalan anak yang ada di keluarga Kristen.

Agar tujuan dapat tercapai, maka dalam memberikan materi dan pembinaan kepada siswa dibutuhkan suatu model pembelajaran yang tepat dan sesuai dengan kondisi di lapangan. Menurut Johnson model pembelajaran Contextual Teaching Learning (CTL) adalah suatu konsep belajar-mengajar yang akan menolong para guru menghubungkan isi permasalahan pelajaran dengan situasi dunia nyata. ${ }^{3}$ Model pembelajaran CTL mengajak dan memotivasi siswa untuk mampu menghubungkan antara ilmu yang

\footnotetext{
${ }^{1}$ Homrighausen, Pendidikan Agama Kristen (Jakarta : BPK Gunung Mulia,1985), 36

${ }^{2}$ Bimo Setyo Utomo, “(R)Evolusi Guru Pendidikan Agama Kristen Dalam Mentransformasi Kehidupan Siswa,” DUNAMIS (Jurnal Teologi dan Pendidikan Kristiani) 1, no. 2 (2017): 102-116, http://www.sttintheos.ac.id/e-journal/index.php/dunamis/article/view/111/100. Band: Oda Judithia Widianing, "Pendidikan Kristen Di Sekolah: Sebuah Tugas Ilahi Dalam Memuridkan Jiwa," Jurnal Teologi Berita Hidup 1, no. 1 (2018): 78-89, https://e-journal.sttberitahidup.ac.id/index.php/jbh.

${ }^{3}$ Elaine B. Johnson, Contextual Teaching \& Learning (Bandung : MLC, 2007), 310
} 
mereka terima dengan kenyataan situasi kehidupan sehari-hari. Model pembelajaran CTL dapat menciptakan suasana dalam proses belajar mengajar menjadi aktif. Tujuan pembelajaran CTL adalah untuk membekali peserta didik dengan pengetahuan dan ketrampilan yang lebih realistis karena inti pembelajaran ini adalah untuk mendekatkan hal-hal yang teoritis ke praktis. ${ }^{4}$ Melalui model pembelajaran CTL dimaksudkan agar tujuan dari pendidikan agama Kristen dapat tercapai yaitu mengenalkan dan mengembangkan karakter Kristiani.

Penelitian dengan menggunakan model pembelajaran CTL telah beberapa kali dilakukan sebelumnya. Penggunaan CTL dilakukan dalam meningkatkan efektivitas pembelajran fisika ${ }^{5}$, atau dalam pembelajaran Kimia ${ }^{6}$. Model pembelajaran CTL telah terbukti mampu meningkatkan efektivitas dan signifikansi pemahaman siswa terhadap materi yang diajarkan. Itu sebabnya penelitian ini memberikan penekananan yang khusus pada proses belajar PAK di SMP 4 Surakarta, sejauh mana model pembelajaran ini efektif meningkatkan karakter Kristiani siswa Sekolah Menengah Pertama Negeri 4 Surakarta.

\section{Metode}

Metode penelitian yang digunakan adalah metode deskriptif analisis. Menurut Natzir, metode deskriptif analisis dilaksanakan untuk menjelaskan secara sistematis, faktual, dan akurat tentang fakta-fakta dan sifat-sifat yang terkait dengan substansi penelitian. ${ }^{7}$ Kriteria efektivitas model pembelajaran Contextual Teaching Learning dapat dilihat melalui pencapaiannya secara praktikal signifikan dan statistikal signifikan. Pada tahap pengujian model, teori dan prinsip-prinsip dasarnya harus memenuhi syarat validasi produk-produk kependidikan melalui penilaian model oleh guru, peneliti dan wakil kepala sekolah bidang kesiswaan. ${ }^{8}$ Perangkat pengujian model pembelajaran Contextual Teaching Learning harus memenuhi syarat: uji validitas dan reliabilitas, Pretest dan Posttest, uji normalitas dan homogenitas data, uji rata-rata dan $N$-gain serta uji beda dua rata-rata.

Hasil pengujian model pembelajaran Contextual Teaching Learning harus memiliki kekuatan dan dinamika perubahan perilaku, dan memiliki karakteristik. Data hasil penelitian harus memperlihatkan data normal dan homogen yang ditunjukkan melalui nilai $\alpha=0,05<$ (nilai sig), sebelum dilakukan pengujian statistik terhadap uji rata-rata dan $\mathrm{N}$-gain serta ujibeda dua rata-rata. Nilai rata-rata dan $N$-gainpre-post yang dihasilkan dari hasil post test harus lebih tinggi dari nilai pre test. Rekapitulasi

\footnotetext{
${ }^{4}$ Ambar Pangaribowo Sakti, Refleksi Pembangunan Karakter Bangsa (Bandung : UPI, 2013), 78

${ }^{5} \mathrm{M}$ Fayakun and P Joko, "Efektivitas Pembelajaran Fisika Menggunakan Model Kontekstual (CTL) Dengan Metodepredict, Observe, Explain Terhadap Kemampuan Berpikir Tingkat Tinggi,” Jurnal Pendidikan Fisika Indonesia 11, no. 1 (2015): 49-58.

${ }^{6}$ Wahyuning Susilowati Lestari, "Pembelajaran Kimia Melalui Pendekatan Contextual Teaching and Learning ( Ctl ) Dengan Metode Praktikum Yang Dilengkapi Dengan Lembar Kerja Siswa ( LKS ) Dan Diagram Vee Ditinjau Dari Perubahan Materi Kelas Vii Semester Genap," Jurnal Pendidikan Kimia (JPK) 1, no. 1 (2012): 107-116.

${ }^{7}$ Natzir, Metode Penelitian (Ghalia Indonesia : Jakarta Timur, 2009), 54-55, 61

${ }^{8}$ Borg \& Gall, Educational Research An Introduction edisi 7 (Boston:Pearson Education, 2003), 570
} 
peningkatan hasil uji beda harus memperlihatkan nilai post test lebih besar dari pre-test, yang ditunjukkan melalui nilai: $\mathrm{t}_{\text {hitung }}>\mathrm{t}_{\text {tabel }}$ atau dilihat nilai $\alpha=0,05>\operatorname{sig}(0,000)$.

Pendekatan penelitian yang dipergunakan adalah pendekatan partisipatif, dan pendekatan mixed method yaitu gabungan penelitian kualitatif dan kuantitatif. Teknik pengumpulan data yang digunakan adalah wawancara, penyebaran angket, Focus Group Discussion (FGD) dan observasi. Sekolah Menengah Pertama Negeri 4 Surakarta dipilih sebagai lokasi penelitian, karena merupakan salah satu dari beberapa sekolah yang ditunjuk oleh Dinas Pendidikan Kota Surakarta sebagai Sekolah percontohan kurikulum 2013, dimaksud untuk membantu anak dalam memaknai pentingnya sebuah karakter dalam dirinya, mampu meningkatkan dan menerapkan karakter yang mulia didalam hidup sehari-hari. Sampel dalam penelitian ini adalah siswa Kristen SMP Negeri 4 Surakarta yang berjumlah 50 orang.

Jenis data yang dikumpulkan dalam penelitian ini adalah data kuantitatif dan data kualitatif. Data kuantitatif dianalisis menggunakan analisis statistik, sedangkan data kualitatif dianalisis menggunakan analisis non statistik. Uji validitas dan reliabilitas skala instrument digunakan untuk menguji skala instrument menurunnya karakter Kristiani siswa Sekolah Menengah Pertama Negeri 4 Surakarta. Sedangkan uji kepraktisan model digunakan untuk merumuskan kelayakan model hipotetik Pembelajaran CTL. Uji kepraktisan model dilakukan oleh para guru sebagai praktisi di lapangan, yang bertujuan untuk melihat berbagai dimensi yang seyogyanya dipertimbangkan dalam pengembangan model pembelajaran CTL, sehingga kelayakan operasional model dapat dipertanggungjawabkan.

\section{Model Pembelajaran CTL}

Menurut Johnson, model pembelajaran CTL merupakan model yang dapat digunakan untuk mengefektifkan dan menyukseskan pendidikan karakter di sekolah sekaligus menciptakan suasana belajar yang lebih bermakna. ${ }^{9}$ Dalam menerapkan CTL terdapat beberapa strategi yang harus ditempuh, seperti: pengajaran berbasis problem; menggunakan konteks yang beragam; mempertimbangkan kebhinekaan peserta didik; memberdayakan peserta didik untuk belajar sendiri; belajar melalui kolaborasi; menggunakan penilaian autentik, dan mengejar standar tinggi. ${ }^{10}$

Model pembelajaran dengan sistem CTL merupakan sebuah proses pendidikan yang bertujuan menolong siswa melihat makna di dalam materi akademik yang mereka pelajari dengan cara menghubungkan subjek-subjek akademik dengan konteks dalam kehidupan keseharian mereka, yaitu dengan konteks keadaan pribadi, sosial dan budaya mereka. ${ }^{11}$ Untuk mencapai tujuan ini, sistem tersebut meliputi delapan komponen berikut : membuat keterkaitan-keterkaitan yang bermakna, melakukan pekerjaan yang berarti, melakukan pembelajaran yang diatur sendiri, melakukan

\footnotetext{
${ }^{9}$ Johnson. E, Contextual Teaching \& Learning (Bandung : Mizan, 2007), 64

${ }^{10}$ Ibid., 21

${ }^{11}$ Elaine B. Jhonson, CTL: Menjadikan Kegiatan Belajar-Mengajar Mengasyikan dan Bermakna (Bandung:Kaifa, 2011), 67
} 
kerjasama, berfikir kritis dan kreatif, membantu individu untuk tumbuh dan berkembang, mencapai standar yang tinggi dan menggunakan penilaian autentik.

Model pembelajaran CTL mencerminkan prinsip saling ketergantungan yang ditampilkan ketika siswa menjalin relasi dengan sesamanya. CTL mencerminkan prinsip diferensiasi ketika mengajak siswa agar mampu menghormati keunikan, perbedaan yang dimiliki oleh orang lain guna menjadi kreatif, kuat dan inovatif. CTL mencerminkan prinsip pengorganisasian diri ketika para siswa mencari dan menemukan kemampuan dan bakat yang dapat membentuk karakter mereka. Landasan filosofi Contextual Teaching Learning adalah konstruktivisme. Kontruksivisme merupakan filosofi belajar yang menekankan bahwa belajar bukan hanya sekedar menghafal tetapi siswa harus mampu mengkonstruksikan pengetahuan di dalam benak mereka sendiri.

\section{Karakter Kristiani}

Karakter Kristiani yang dimaksud dalam penelitian ini mencakup kasih, kejujuran, kedisiplinan, dan tanggungjawab. Kasih merupakan dasar bagi hidup orang Kristen. Hal itu dapat dilihat dalam Kitab 1 Korintus 13:13, "demikianlah tinggal ketiga hal ini, yaitu iman, pengharapan dan kasih, dan yang paling besar di antaranya ialah kasih." Kasih di sini memiliki ciri yaitu sabar, murah hati, tidak cemburu, tidak memegahkan diri dan tidak sombong, tidak melakukan yang tidak sopan, tidak mencari keuntungan sendiri, tidak pemarah dan tidak menyimpan kesalahan orang lain. ${ }^{12}$ Menurut Malcolm Kasih Kristen memiliki arti yaitu: "memberi diri kepada orang lain. Kasih berarti kesediaan untuk mengorbankan diri sendiri untuk orang lain seperti Kristus mengorbankan diriNya untuk kita. Kasih Kristen diberikan tanpa pamrih, tidak menuntut balasan dan tidak berdasarkan keinginan untuk menerima sesuatu dari orang yang dikasihi."13

Menurut Tesaurus Bahasa Indonesia jujur berarti andal, benar, bersih, lurus. Kejujuran adalah integritas, kelurusan hari, ketulusan, kepolosan. ${ }^{14}$ Secara Alkitabiah jujur memiliki arti seperti yang tertulis dalam Matius 5:37 yaitu "Jika ya, hendaklah kamu katakan ya, jika tidak hendaklah kamu katakan tidak. Apa yang lebih daripada itu berasal dari si jahat." Kejujuran merupakan sebuah integritas dan kebenaran yang membutuhkan suatu keseimbangan antara apa yang dipikirkan, diucapkan dan dilakukan sama. Selain itu, di dalam Alkitab juga dijelaskan dampak dari ketidakjujuran yaitu kematian seperti Ananias dan Safira (KPR 5:1-11).

Prawirosentono mengemukakan bahwa secara umum kedisiplinan adalah taat kepada hukum dan peraturan yang berlaku. ${ }^{15}$ Sedangkan menurut Suradinata, kedisiplinan pada dasarnya mencakup pelajaran, patuh, taat, kesetiaan, hormat kepada

\footnotetext{
${ }^{12}$ Ibid., 207

${ }^{13}$ Malcolm Brown, Pengambilan Keputusan Etis dan Faktor-faktor di dalamnya (Jakarta : BPK Gunung Mulia,2006), 205

${ }^{14}$ Eko Endarmoko, Tesaurus Bahasa Indonesia (Jakarta : Gramedia Pustaka Utama, 2007), 278

${ }^{15}$ Suyadi Prawirosentono, Manajemen Sumber Daya Manusia, Kebijakan Kinerja Karyawan (Yogyakarta : BPFE,1999), 31
} 
ketentuan/peraturan/norma yang berlaku. ${ }^{16}$ Secara alkitabiah kedisplinan juga dijelaskan oleh Rasul Paulus. Kedisiplinan di sini adalah kedisplinan dalam hal kerohanian seperti yang tertulis dalam 2 Timotius 1:7 "sebab Allah memberikan kepada kita bukan roh ketakutan, melainkan roh yang membangkitkan kekuatan, kasih dan ketertiban."

Menurut Tesaurus bahasa Indonesia, tanggungjawab adalah konsekuen, konsisten. ${ }^{17}$ Secara umum tanggungjawab adalah keadaan wajib menanggung segala sesuatunya atau sikap mau menerima tugas dengan segala konsekuensinya kemudian melakukannya dengan setia. ${ }^{18}$ Selain itu Alkitab juga menegaskan akan pentingnya tanggungjawab. Hal itu dapat dilihat dalam perumpamaan tentang talenta yang tertulis dalam Matius 25:14-30. Dalam perumpamaan tentang talenta itu dijelaskan bagaimana tanggungjawab seseorang dalam melaksanakan tugas yang diberikan oleh tuannya. Bagi hamba yang melaksanakan tugasnya dengan penuh tanggungjawab, maka dia akan mendapatkan upah, tetapi sebaliknya bagi hamba yang tidak menjalankan tugasnya dengan tanggungjawab, maka dia mendapat sanksi.

\section{Hasil dan Pembahasan}

Munculnya perilaku menyimpang dari siswa Sekolah Menengah Pertama merupakan tanda dari lunturnya karakter dalam diri siswa. Jika dicermati karakter bukanlah suatu sikap yang muncul secara tiba-tiba, melainkan dibutuhkan suatu proses yang lama dan berkelanjutan. Permasalahan karakter Kristiani dalam diri siswa Sekolah Menengah Pertama terletak pada ketidakmampuannya dan belum memahami aspek-aspek yang ada dalam karakter Kristiani yaitu kasih, kejujuran, kedisiplinan dan tanggungjawab. Model pembelajaran CTL membantu siswa dan guru untuk bersikap kritis dan mampu untuk mengkaitkan antara materi yang mereka terima dengan lingkungan di sekitarnya. Model pembelajaran ini juga membantu dalam menangani permasalahan tentang pemahaman materi di dalam diri siswa.

\section{Penerapan Model Contextual Teaching Learning}

Contextual Teaching Learning (CTL) merupakan model yang dapat digunakan untuk mengefektifkan dan menyukseskan pendidikan karakter di sekolah sekaligus menciptakan suasana belajar yang lebih bermakna. ${ }^{19}$ Menurut Taniredja, ada tujuh komponen utama dalam model pembelajaran CTL yaitu (1) kontruksivisme (constructivisme), (2) bertanya (questioning), (3) menemukan (inquiry), (4) masyarakat belajar (learning community), (5) permodelan (modeling), (6) refleksi dan (7) penilaian sebenarnya. ${ }^{20}$

\footnotetext{
${ }^{16}$ ErmayaSuradinata, Manajemen Sumber Daya Manusia,(Bandung : CV Ramadhan,1996), 150

${ }^{17}$ Eko Endarmoko.Tesaurus Bahasa Indonesia.(Jakarta : Gramedia Pustaka Utama, 2007).Hal 278

${ }^{18}$ Kelompok Kerja PAK-PGI, Cermin Remaja 3: Hidup yang Berubah (Jakarta : BPK Gunung Mulia, 2011), 2

${ }^{19}$ Johnson, Contextual Teaching \& Learning, 64

${ }^{20}$ Taniredja, T, dkk., Model Model Pembelajaran Inovatif (Bandung Alfabeta, 2011), 49
} 


\section{Konstruksivisme}

Menurut Sanjaya, konstruksivisme adalah proses membangun atau menyusun pengetahuan baru dalam struktur kognitif siswa berdasarkan pengalaman. Menurut konstruksivisme, pengetahuan itu memang berasal dari luar akan tetapi dikonstruksi dari dalam diri seseorang. ${ }^{21}$ Dalam memahami suatu materi tidak hanya dengan cara menghafal saja melainkan siswa diajak untuk bisa mengkonstruksikan dengan pengalaman yang ada dalam hidup dan dirinya. Penerapan model pembelajaran CTL dalam Pendidikan Agama Kristen dapat membantu siswa dalam menghubungkan antara pengalaman pribadinya dengan materi yang dia terima.

Siswa diajak melakukan pengamatan di luar kelas. Setelah selesai siswa diminta untuk menganalisis hasil pengamatan tersebut dan menuliskannya di buku. Model pembelajaran ini dapat membantu siswa untuk membangun suatu pengetahuan berdasarkan pada pengalaman yang ada. Contohnya untuk materi pembelajaran pertobatan, siswa diminta untuk menceritakan pengalaman yang pernah mereka alami, kemudian dituliskan di selembar kertas. Hal ini bertujuan untuk melatih ketrampilan mereka untuk menggabungkan antara materi pembelajaran dengan pengalaman mereka.

\section{Menemukan}

Menurut Sanjaya, inquiry adalah "proses pembelajaran yang didasarkan dari pencarian dan penemuan melalui proses berfikir secara sistematis dan dilakukan melalui beberapa langkah yaitu merumuskan masalah, mengajukan hipotesis, mengumpulkan data, menguji hipotesis dan membuat kesimpulan."22 Dalam aspek ini, siswa diajak untuk memiliki kemampuan dalam menemukan pemahaman, makna dari pengetahuan atau materi yang mereka terima. Aspek ini mengajak siswa untuk bisa meningkatkan ketrampilan mereka dalam mengelola pengetahuan yang mereka peroleh berdasarkan pada fakta yang ada di lingkungan. Contohnya siswa diminta untuk melakukan pengamatan di lingkungan di mana mereka berada berkaitan dengan sikap hidup orang yang mengasihi. Mengasihi di sini bisa dilakukan terhadap saudara, teman atau orang tua. Kemudian hal itu dituliskan di buku untuk dipresentasikan.

\section{Bertanya}

Menurut Mulyasa, ada 6 ketrampilan bertanya dalam kegiatan pembelajaran yaitu pertanyaan yang jelas dan singkat, memberi acuan, memusatkan perhatian, memberi giliran dan menyebarkan pertanyaan, pemberian kesempatan berfikir, dan pemberian tuntunan. ${ }^{23}$ Aspek ini mengajak siswa untuk mampu berfikir lebih mendalam akan sesuatu hal yang telah mereka terima, sehingga mereka bisa mempertanggungjawabkannya. Misalnya ketika guru menjelaskan suatu materi kemudian ada salah satu

\footnotetext{
${ }^{21}$ Wina Sanjaya, Strategi Pembelajaran Berbasis Kompetensi dan Kontekstual (Jakarta: Bumi Aksara, 2009), 264

${ }^{22}$ Ibid., 265

${ }^{23}$ Enco Mulyasa, Menjadi Guru Profesional (Bandung: Rosda Karya, 2009), 70
} 
siswa yang bertanya. Hal ini menunjukkan bahwa ada rasa ingin tahu dalam diri siswa yang dimunculkan melalui sikap yang mau bertanya.

\section{Proses Belajar}

Model pembelajaran Contextual Teaching Learning mengajak siswa dan pendidik untuk bisa menghubungkan dan menjalin relasi dengan masyarakat sekitar. Tujuan dari Pendidikan Agama Kristen dapat tercapai, jika dalam proses belajar mengajar siswa mampu menghubungkan serta menerapkan ilmunya di dalam kehidupan mereka. Menurut Muslich, konsep masyarakat belajar dalam CTL adalah: "hasil pembelajaran diperoleh melalui kerjasama dengan orang lain. Hal ini berarti bahwa hasil belajar bisa diperoleh dengan sharing antar teman, antar kelompok, dan antar yang tahu kepada yang tidak tahu, baik di dalam maupun di luar kelas." 24

Contohya guru memberikan suatu studi kasus kepada siswa tentang masyarakat majemuk, kemudian siswa diminta untuk memberikan solusi terhadap kasus yang mereka hadapi dengan membahasnya secara berkelompok. Pelaksanaan sosiodrama dalam proses pembelajaran Pendidikan Agama Kristen juga dilakukan dengan tujuan untuk mengkontekstualisasikan materi pembelajaran ke dalam kehidupan sehari-hari.

\section{Permodelan}

Menurut Wina Sanjaya, permodelan adalah proses pembelajaran dengan memperagakan sesuatu sebagai contoh yang dapat ditiru oleh setiap siswa. ${ }^{25}$ Permodelan mengajak siswa untuk mampu memahami secara lebih nyata akan suatu materi pembelajaran yang mereka terima. Aspek permodelan ini membantu siswa untuk bisa memahami sesuatu hal secara nyata. Pemodelan dapat diwujudkan melalui demonstrasi, pemberian contoh tentang konsep atau aktivitas belajar. Guru memberikan model tentang bagaimana cara belajar. Dalam pembelajaran kontekstual, guru bukan satu-satunya model, akan tetapi model dapat dirancang dengan melibatkan siswa atau juga dapat dari luar.

Permodelan atau teladan dapat membantu siswa dalam mengaplikasikan suatu karakter kristiani dalam hidup mereka. Permodelan atau teladan merupakan hal yang penting dalam membantu siswa untuk mengembangkan dan meningkatkan karakternya. Melalui permodelan, para guru bisa memberikan contoh yang karakter kristiani agar bisa diterapkan dalam kehidupan para siswa. Ada pepatah yang mengatakan "guru iku digugu lan ditiru." Seorang guru harus mampu menjadi teladan dan permodelan bagi para siswa.

\section{Refleksi}

Menurut Wina Sanjaya, refleksi adalah proses pengendapan pengalaman yang telah dipelajari dengan cara mengurutkan kembali kejadian-kejadian atau peristiwa pembelajaran yang telah dilaluinya. Dalam proses pembelajaran dengan CTL, pada setiap akhir

\footnotetext{
${ }^{24}$ Mansur Muslich, KTSP Pembelajaran Berbasis Kompetensi dan Kontekstual (Jakarta:Bumi Aksara,2009), 46

${ }^{25}$ Wina Sanjaya, Strategi Pembelajaran Berbasis Kompetensi dan Kontekstual, 267
} 
proses pembelajaran, guru memberikan kesempatan kepada siswa untuk merenungkan atau mengingat kembali apa yang telah dipelajarinya. ${ }^{26}$ Refleksi mengajak para siswa untuk mampu menilai diri mereka sendiri yang kemudian digunakan sebagai acuan untuk memperbaiki diri mereka sendiri.

\section{Penilaian Nyata}

Penilaian nyata berfungsi untuk memberikan apresiasi berupa nilai kepada siswa yang mampu memahami dan melakukan apa yang menjadi tujuan dari pembelajaran. Menurut Muslich penilaian autentik adalah: "proses pengumpulan berbagai data yang bisa memberikan gambaran atau informasi tentang perkembangan pengalaman belajar siswa. Gambaran perkembangan pengalaman belajar siswa perlu diketahui oleh guru setiap saat agar bisa memastikan bahwa siswa mengalami proses pembelajaran yang benar." ${ }^{27}$ Penilaian nyata disini tidak hanya berupa nilai ketika mereka mengikuti tes melainkan juga dapat melalui nilai ketika mereka bersikap dalam mengikuti pembelajaran.

Seorang pendidik memberikan nilai bukan hanya berdasarkan pada nilai akhir ketika ulangan melainkan juga harus memperhatikan sikap dan perilaku siswa ketika mengikuti pembelajaran. Jadi dalam hal ini penilaian nyata dilakukan bukan berdasarkan pada kedekatan siswa dengan guru atau hanya berdasarkan pada hasil tes saja melainkan berdasarkan pada keseluruhan kehidupan dan proses yang dilakukan oleh siswa ketika mereka menerima pelajaran dan ketika mereka berelasi dengan sesama.

\section{Hasil Pengolahan Data}

Berikut ini disajikan hasil uji beda dua rata-rata (paired sample test) sebagai berikut :

Tabel 1: Hasil Uji Beda Dua Rata-Rata Pretest-Posttest Karakter Kristiani dengan

Model Pembelajaran Contextual Teaching Learning

\begin{tabular}{|l|l|l|l|l|l|l|l|}
\hline No & $\begin{array}{l}\text { Perkembangan dan } \\
\text { Dimensi Spiritual }\end{array}$ & Kelompok & Mean & df & Thitung & Ttabel & $\begin{array}{l}\text { Sig } \\
(2 \text {-tailed })\end{array}$ \\
\hline 1 & Kasih & $\begin{array}{l}\text { Pre Test- } \\
\text { Post Test }\end{array}$ & 1,420 & 49 & 11,685 & 1,684 & 0,000 \\
& Kejujuran & $\begin{array}{l}\text { Pre Test- } \\
\text { Post Test }\end{array}$ & 4,280 & 49 & 26,614 & 1,684 & 0,000 \\
\hline 4 & Kedisiplinan & $\begin{array}{l}\text { Pre Test- } \\
\text { Post Test }\end{array}$ & 2,600 & 49 & 17,513 & 1,684 & 0,000 \\
\hline
\end{tabular}

\footnotetext{
${ }^{26}$ Ibid., 268

${ }^{27}$ Mansur Muslich, KTSP Pembelajaran Berbasis Kompetensi dan Kontekstual, 147
} 
Tabel 2: Hasil Pre Test dan Post Test Karakter Kristiani dengan Model Pembelajaran Contextual Teaching Learning

\begin{tabular}{|c|c|c|c|c|c|c|}
\hline No & Aspek & Indikator & $\begin{array}{l}\text { Presentase } \\
\text { Pre Test }\end{array}$ & $\begin{array}{c}\text { Rekapitulasi } \\
\text { Rerata }\end{array}$ & $\begin{array}{c}\text { Presentase } \\
\text { Post Test }\end{array}$ & $\begin{array}{c}\text { Rekapitulasi } \\
\text { Rerata }\end{array}$ \\
\hline \multirow[t]{2}{*}{1} & \multirow[t]{2}{*}{ Kasih } & \multirow{2}{*}{$\begin{array}{l}\text { Penerapan } \\
\text { kasih dalam } \\
\text { hidup siswa }\end{array}$} & 40,00 & \multirow{2}{*}{$\begin{array}{l}\text { Kasih } \\
40,55 \%\end{array}$} & 81,50 & \multirow{2}{*}{$\begin{array}{l}\text { Kasih } \\
80,25 \%\end{array}$} \\
\hline & & & 41,00 & & 79,00 & \\
\hline \multirow[t]{4}{*}{2.} & \multirow[t]{4}{*}{ Kejujuran } & \multirow{4}{*}{$\begin{array}{l}\text { Perilaku yang } \\
\text { jujur ketika } \\
\text { melaksanakan } \\
\text { kewajiban, }\end{array}$} & 45,00 & \multirow{4}{*}{$\begin{array}{l}\text { Kejujuran } \\
41,38 \%\end{array}$} & 82,00 & \multirow{4}{*}{$\begin{array}{l}\text { Kejujuran } \\
88,38 \%\end{array}$} \\
\hline & & & 34,50 & & 85,50 & \\
\hline & & & 41,00 & & 86,00 & \\
\hline & & & 44,50 & & 80,00 & \\
\hline \multirow[t]{2}{*}{3} & \multirow{2}{*}{$\begin{array}{l}\text { Kedisipl } \\
\text { inan }\end{array}$} & \multirow{2}{*}{$\begin{array}{l}\text { Ketaatan } \\
\text { terhadap tata } \\
\text { tertib yang } \\
\text { ada }\end{array}$} & 38,00 & \multirow{2}{*}{$\begin{array}{l}\text { Kedisiplinan } \\
32,25 \%\end{array}$} & 75,00 & \multirow{2}{*}{$\begin{array}{l}\text { Kedisiplinan } \\
81,50 \%\end{array}$} \\
\hline & & & 32,50 & & 88,00 & \\
\hline \multirow[t]{2}{*}{4} & \multirow{2}{*}{$\begin{array}{l}\text { Tanggu } \\
\text { ng } \\
\text { Jawab }\end{array}$} & \multirow{2}{*}{$\begin{array}{l}\text { Sikap maupun } \\
\text { perilaku } \\
\text { tanggungjawab } \\
\text { ketika } \\
\text { menjalankan } \\
\text { tugas dari guru }\end{array}$} & 46,00 & \multirow{2}{*}{$\begin{array}{l}\text { Tanggungja } \\
\text { wab } \\
44,25 \%\end{array}$} & 87,50 & \multirow[t]{2}{*}{$\begin{array}{l}\text { Tanggungjawab } \\
85,50 \%\end{array}$} \\
\hline & & & 42,50 & & 83,50 & \\
\hline \multicolumn{5}{|c|}{ Kasih $=40,55 \%$} & \multicolumn{2}{|c|}{ Kasih $=80,25 \%$} \\
\hline \multicolumn{5}{|c|}{ Kejujuran $=41,38 \%$} & \multicolumn{2}{|c|}{ Kejujuran $=88,38 \%$} \\
\hline \multicolumn{5}{|c|}{ Kedisiplinan $=32,25 \%$} & \multicolumn{2}{|c|}{ Kedisiplinan $=81,50 \%$} \\
\hline \multicolumn{5}{|c|}{ Tanggungjawab $=44,25 \%$} & \multicolumn{2}{|c|}{ Tanggungjawab $=85,50 \%$} \\
\hline
\end{tabular}

Berdasarkan pada kedua tabel di atas terlihat bahwa :

Aspek kasih dalam karakter Kristiani memiliki nilai $\alpha=0,05>$ sig $(0,000)$, sehingga model pembelajaran CTL terbukti meningkatkan aspek kasih dalam karakter Kristiani. Aspek kejujuran dalam karakter Kristiani memiliki nilai $\alpha=0,05>\operatorname{sig}(0,000)$, sehingga model pembelajaran CTL terbukti meningkatkan aspek kejujuran dalam karakter Kristiani. Aspek kedisiplinan dalam karakter Kristiani memiliki nilai $\alpha=0,05>$ sig $(0,000)$, sehingga model pembelajaran CTL terbukti meningkatkan aspek kedisiplinan dalam karakter Kristiani. Aspek tanggung jawab dalam karakter Kristiani memiliki nilai $\alpha=0,05>$ sig $(0,000)$, sehingga model pembelajaran CTL terbukti meningkatkan aspek tanggung jawab dalam karakter Kristiani.

\section{Hasil Analisis Kualitatif}

Kasih

Model pembelajaran CTL memampukan siswa untuk mewujudkan sikap kasih kepada Allah melalui berbuat baik kepada sesamanya. Kasih yang dijadikan dasar adalah kasih agape, yaitu kasih yang tulus dan tanpa pamrih. Keteladanan mampu membantu siswa untuk memahami dan mewujudkan karakter Kristiani yaitu kasih. Karakter Kristiani yaitu kasih mengalami peningkatan karena penerapan model pembelajaran CTL dalam Pendidikan Agama Kristen. Model pembelajaran CTL 
melalui aspek permodelan mampu membantu anak dalam memahami makna dan mewujudkan sikap kasih dalam hidup mereka. Sikap dan wujud dari kasih itu misalnya mengampuni orang yang pernah menyakiti kita, peduli kepada sesama yang menderita, tidak membedakan kasih dalam keluarga.

\section{Kejujuran}

Sebelum penerapan model pembelajaran CTL aspek kejujuran dalam karakter Kristiani belum sepenuhnya bisa dipahami dan dilakukan oleh siswa. Model pembelajaran CTL membawa siswa bisa memahami kejujuran dengan cara yang benar. Melalui penerapan model pembelajaran CTL siswa mampu memahami kejujuran dan mengaplikasikannya dalam hidup mereka yaitu melalui sikap hidup tidak mencontek ketika ulangan, membayarkan uang SPP serta berani berkata "ya" jika itu memang benar dan "tidak" jika itu memang bukan suatu kebenaran.

\section{Tanggungjawab}

Model pembelajaran CTL mampu mengajak siswa mewujudkan tanggungjawabnya dalam melaksanakan tugas. Tanggungjawab siswa mampu dimunculkan ketika mereka menerima tugas untuk memimpin pujian. Mereka melaksanakannya dengan penuh kesungguhan hati dan tidak menggerutu. Sikap tanggungjawab itu muncul karena siswa sudah memahami akan makna dan manfaat dari tanggungjawab bagi hidup mereka. Melalui model pembelajaran CTL siswa mampu memahami makna dari tanggungjawab dan aplikasinya dalam kehidupan sehari-hari. Misalnya ketika diberikan tugas memimpin pujian, membawakan renungan dapat dilaksanakan dengan baik dan tidak menggerutu.

Sebelum penerapan model pembelajaran CTL masih banyak siswa yang mengalami permasalahan pemahaman akan makna dan aplikasi dari karakter Kristiani. Hal terlihat dari sikap dan perilaku siswa yang masih sering melanggar aturan dan norma yang ada. Pelanggaran yang sering dilakukan oleh siswa misalnya mencontek ketika ulangan, membolos sekolah, menolak ketika diberikan tugas memimpin pujian, berkata kotor, membantu siswa ketika ulangan dan tidak mengikuti pelajaran dengan baik. Siswa mengalami permasalahan pemahaman karena mereka masih mengalami kebingungan dan tidak tahu isi dari materi yang mereka terima.

Model pembelajaran CTL yang diterapkan secara efektif dapat meningkatkan karakter Kristiani siswa SMPN 4 Surakarta. Keefektifan tersebut terlihat dari sikap siswa dalam memaknai dan melakukan karakter Kristiani dalam hidup mereka. Model pembelajaran CTL dapat diterima oleh siswa dan membuat siswa lebih mengerti akan materi pembelajaran yang mereka terima sehingga mereka dapat mengaplikasikan di dalam hidupnya. Model pembelajaran CTL juga membantu siswa dalam mengatasi permasalahan pemahaman akan makna dan aplikasi dari karakter Kristiani.

Keefektivan model pembelajaran CTL juga dapat dilihat dari hasil observasi yang menyatakan bahwa melalui model pembelajaran ini sikap dan perilaku siswa mengalami peningkatan. Perubahan dan peningkatan sikap serta perilaku siswa dapat dimunculkan 
melalui sikap yang bersedia menerima tugas dari guru yaitu untuk memimpin pujian yang dapat dilakukan dengan kesungguhan hati, mengumpulkan tugas tepat waktu, mengikuti proses pembelajaran pendidikan Agama Kristen dengan tertib, mengikuti ibadah pagi secara rutin, serta tidak berkata kotor kepada teman. Sikap-sikap di atas membuktikan bahwa mereka sudah bisa membedakan mana hal yang harus dilakukan dan dihindari. Siswa juga telah mampu mewujudkan sikap kasih dengan benar, menerapkan sikap disiplin yaitu dengan dating ke sekolah tepat waktu, mengikuti kebaktian serta berani untuk menjadi pemimpin pujian serta membawakan renungan. Semua temuan ini membuktikan bahwa model pembelajaran CTL efektif dalam meningkatkan karakter Kristiani siswa Sekolah Menengah Pertama Negeri 4 Surakarta.

\section{Kesimpulan}

Model pembelajaran CTL mengajak siswa untuk memiliki kemampuan dan kemauan di dalam menggabungkan serta menyusun pengetahuan yang mereka terima kemudian mereka kaitkan dengan pengalaman kehidupan mereka serta lingkungan di mana mereka tinggal. Pelaksanaan model pembelajaran CTL terbukti efektif dalam meningkatkan karakter Kristiani siswa SMPN 4 Surakarta. Hal itu dapat terlihat melalui perubahan sikap dalam diri mereka. Misalnya mampu memimpin pujian dan membawakan renungan, datang ke sekolah tepat waktu, selalu mengikuti ibadah pagi dan tidak bersungut-sungut jika mendapatkan tugas dari guru.

\section{Referensi}

Borg \& Gall. Educational Research An Introduction edisi 7, Boston: Pearson Education. 2003

Brown, Malcolm. Pengambilan Keputusan Etis dan Faktor-Faktor di Dalamnya, Jakarta: BPK Gunung Mulia, 2006

Fayakun, M, and P Joko. "Efektivitas Pembelajaran Fisika Menggunakan Model

Kontekstual (CTL) Dengan Metodepredict, Observe, Explain Terhadap

Kemampuan Berpikir Tingkat Tinggi." Jurnal Pendidikan Fisika Indonesia 11, no. 1 (2015): 49-58.

Johnson, Elaine B. Contextual Teaching \& Learning, Bandung: MLC, 2003.

Endarmoko, Eko. Tesaurus Bahasa Indonesia, Jakarta: Gramedia Pustaka Utama, 2007. Johnson, Elaine B. Contextual Teaching and Learning, Bandung : MLC, 2007.

Kelompok Kerja PAK-PGI. Suluh Siswa 1 Bertumbuh dalam Kristus, Jakarta: BPK Gunung Mulia, 2009.

Lestari, Wahyuning Susilowati. "Pembelajaran Kimia Melalui Pendekatan Contextual

Teaching and Learning ( $\mathrm{Ctl}$ ) Dengan Metode Praktikum Yang Dilengkapi Dengan Lembar Kerja Siswa ( LKS ) Dan Diagram Vee Ditinjau Dari Perubahan Materi Kelas Vii Semester Genap.” Jurnal Pendidikan Kimia (JPK) 1, no. 1 (2012): 107116.

Mulyasa, Enco. Menjadi Guru Profesional, Bandung: Rosda Karya, 2009.

Muslich, Mansur. KTSP Pembelajaran Berbasis Kompetensi dan Kontekstual, Jakarta: Bumi Aksara, 2009.

Moh Natzir. Metode Penelitian, Jakarta Timur: Ghalia Indonesia, 2009

Sakti, Ambar Pangaribowo Sakti. Refleksi Pembangunan Karakter Bangsa, Bandung : UPI, 2013 
Sanjaya, Wina. Strategi Pembelajaran Berbasis Kompetensi dan Kontekstual, Jakarta: Bumi Aksara, 2009.

Suradinata, Ermaya. Manajemen Sumber Daya Manusia, Bandung: CV Ramadhan, 1996.

Prawirosentono, S. Manajemen Sumber Daya Manausia, Kebijakan Kinerja Karyawan, Yogyakarta: BPFE, 1999.

Taniredja, T, dkk. Model Model Pembelajaran Inovatif, Bandung: Alfabeta, 2011.

Utomo, Bimo Setyo. “(R)Evolusi Guru Pendidikan Agama Kristen Dalam Mentransformasi Kehidupan Siswa." DUNAMIS (Jurnal Teologi dan Pendidikan Kristiani) 1, no. 2 (2017): 102-116. http://www.sttintheos.ac.id/ejournal/index.php/dunamis/article/view/111/100.

Widianing, Oda Judithia. "Pendidikan Kristen Di Sekolah: Sebuah Tugas Ilahi Dalam Memuridkan Jiwa.” Jurnal Teologi Berita Hidup 1, no. 1 (2018): 78-89. https://ejournal.sttberitahidup.ac.id/index.php/jbh. 